\title{
The human homologs of checkpoint kinases Chk1 and Cds1 (Chk2) phosphorylate p53 at multiple DNA damage-inducible sites
}

\author{
Sheau-Yann Shieh, ${ }^{1,2}$ Jinwoo Ahn, ${ }^{1}$ Katsuyuki Tamai, ${ }^{4}$ Yoichi Taya, $^{3}$ and Carol Prives ${ }^{1,5}$ \\ ${ }^{1}$ Department of Biological Sciences, Columbia University, New York, New York 10027 USA; ${ }^{2}$ National Cancer Research \\ Institute, Tokyo 104, Japan; ${ }^{3}$ Cyclex Company Ltd., Nagano, 396-0002, Japan
}

Upon DNA damage, the amino terminus of 553 is phosphorylated at a number of serine residues including S20, a site that is particularly important in regulating stability and function of the protein. Because no known kinase has been identified that can modify this site, HeLa nuclear extracts were fractionated and S20 phosphorylation was followed. We discovered that a S20 kinase activity copurifies with the human homolog of the Schizosaccharomyces pombe checkpoint kinase, Chk1 (hCHK1). We confirmed that recombinant hCHK1, but not a kinase-defective version of hCHK1, can phosphorylate p53 in vitro at S20. Additional inducible amino- and carboxy-terminal sites in p53 are also phosphorylated by hCHK1, indicating that this is an unusually versatile protein kinase. It is interesting that hCHK1 strongly prefers tetrameric to monomeric p53 in vitro, consistent with our observation that phosphorylation of amino-terminal sites in vivo requires that 553 be oligomeric. Regulation of the levels and activity of hCHK1 in transfected cells is directly correlated with the levels of p53; expression of either a kinase-defective hCHK1 or antisense hCHK1 leads to reduced levels of cotransfected p53, whereas overexpression of wild-type hCHK1 or the kinase domain of hCHK1 results in increased levels of expressed p53 protein. The human homolog of the second S. pombe checkpoint kinase, Cds1 (CHK2/hCds1), phosphorylates tetrameric p53 but not monomeric p53 in vitro at sites similar to those phosphorylated by hCHK1 kinase, suggesting that both checkpoint kinases can play roles in regulating p53 after DNA damage.

[Key Words: hCHK1; hChk2/Cas1;p53; DNA damage; S. pombe]

Received December 8, 1999; revised version accepted December 29, 1999.

Upon sources of cellular stress such as damaged DNA, the p53 tumor suppressor protein is stabilized and activated via post-transcriptional mechanisms, and this leads to growth arrest or apoptosis (Levine 1997; Agarwal et al. 1998; Schwartz and Rotter et al. 1998). These cellular responses may be carried out by downstream targetgene products that are involved in $G_{1}$ or $G_{2}$ growth arrest, notably p21/WAF1 or 14-3-3y, respectively; or which regulate apoptosis, such as Bax, IGFBP3, and PIG genes among many others (for review, see El-Deiry 1998). Another p53 target gene, $M D M 2$, encodes a p53-binding protein that negatively regulates the activity (Momand et al. 1992; Oliner et al. 1993) and the stability of p53 (Haupt et al. 1997; Kubbutat et al. 1997; Midgley and Lane 1997).

In comparison with studies characterizing the down-

\footnotetext{
${ }^{4}$ Present address: Institute of Biomedical Sciences, Academia Sinica, Nankkang, Taipei 11529, Taiwan.

${ }^{5}$ Corresponding author.

E-MAIL clp3@columbia.edu; FAX (212) 865-8246.
}

stream responses to p53 induction, much less is known about the upstream signaling events that lead to activation and stabilization of this protein. p53 is phosphorylated at several serine residues within its amino- and carboxy-terminal domains and is also acetylated at lysines within the carboxy-terminal portion of the molecule (for review, see Meek 1998). Many of these modifications are inducible upon DNA damage. For example, phosphorylation at S15, S20, S33, and S37 at the amino terminus is induced by UV and ionizing radiation (IR), whereas phosphorylation at S392 within the carboxyl terminus is induced only by UV but not by IR (for review, see Giaccia and Kastan 1998 and Prives 1998). Simultaneous mutation of multiple amino-terminal sites reduces the transactivation function of p53 (Mayr et al. 1995). Promoter and cell-type-specific effects were also observed for phosphorylation site mutants (Lohrum and Scheidtmann 1996). Phosphorylation at S392 was shown to facilitate tetramerization (Sakaguchi et al. 1997) and enhance DNA binding by p53 (Hupp et al. 1992; Hupp and Lane 1994). Protein kinases that phosphorylate hu- 
man and/or murine p53 in vitro include casein kinase I (CKI; Milne et al. 1992), casein kinase II (CKII; Meek et al. 1990), the DNA-activated protein kinase (DNA-PK; Lees-Miller et al. 1990), ATM kinase (Banin et al. 1998; Canman et al. 1998; Khanna et al. 1998), ATR kinase (Canman et al. 1998; Tibbetts et al. 1999), S and G2specific cyclin dependent kinase (CDKs; Wang and Prives 1995), cdk-activating kinase (CAK; Ko et al. 1997), protein kinase-C (PKC; Baudier et al. 1992), protein kinase R (PKR; Cuddihy et al. 1999), Jun-amino-terminal kinases (JNKs; Milne et al. 1995; Adler et al. 1997; Hu et al. 1997), raf-1 (Jamal and Ziff 1995), and mitogen-activated protein kinase (MAPK; Milne et al. 1994). Several of these kinases phosphorylate p53 in vitro at sites known to be modified in response to DNA damage in cells: ATM, ATR, and DNA-PK on S15 (Shieh et al. 1997; Siliciano et al. 1997), CAK on S33 (Ko et al. 1997), ATR and DNA-PK on S37 (Sakaguchi et al. 1998), and CKII on S392 (Blades and Hupp 1998; Kapoor and Lozano 1998; Lu et al. 1998). In particular, the ATM kinase has received a great deal of attention, because the p53 response is diminished or delayed in ATM-deficient cells after IR (Kastan et al. 1992; Lu and Lane 1993), and the ability of ATM to phosphorylate p53 is increased after cells are irradiated (Banin et al.1998; Canman et al. 1998). It is very likely, however, that additional protein kinases are involved in signaling to and the ensuing stabilization and activation of p53.

In eukaryotes, genome stability is maintained by cell cycle checkpoints. Recent studies with yeast have shed light on these processes by connecting such checkpoints with genes involved in mitotic control (for review, see Elledge 1996; Weinert 1998). The conservation of many checkpoint genes between yeast and mammals has also become apparent. Notably, the budding yeast Mec1, Tel1, and the fission yeast rad3 are the structural homologs of mammalian ATM and ATR genes (for review, see Lavin and Shiloh 1997). In fission yeast, DNA damage or stalled replication forks activate $\operatorname{rad} 3$, which then leads to phosphorylation and activation of the Chk1 or Cds1 protein kinases, respectively (Walworth and Bernards 1996; Martinho et al. 1998). Both Chk1 and Cds1 prevent activation of Cdc2 by phosphorylating and inactivating Cdc25 (Furnari et al. 1997; Peng et al. 1997; Zeng et al. 1998). Mammalian homologs of yeast Chk1 (Flaggs et al. 1997; Sanchez et al. 1997) and Cds1 (Matsuoka et al. 1998; Blasina et al. 1999; Brown et al. 1999; Chaturvedi et al. 1999/ genes have been identified, and the activity of human Cds1 (CHK2/hCds1) appears to require functional ATM (Matsuoka et al. 1998; Brown et al. 1999; Chaturvedi et al. 1999). Despite their structural and functional similarities, differences do exist between the yeast and mammalian pathways. For example, yeast Rad3 responds to $\gamma$ and UV irradiation as well as agents that block DNA replication, whereas mammalian ATM responds only to $\gamma$ irradiation. Furthermore, although yeast Chk1, rather than Cds1, is the major effector in the DNA damage-induced checkpoint, CHK2/hCds1 is activated by $\gamma$ treatment (Matsuoka et al. 1998; Brown et al. 1999|, suggesting that the functions of hCHK1 and
$\mathrm{CHK} 2 / \mathrm{hCd} 1$ may be more redundant in human than in their yeast counterparts.

We discovered recently that a novel site, S20, within the amino terminus of p53 is phosphorylated in response to $\gamma$ irradiation (Shieh et al. 1999). This site is of particular interest because it lies directly within the MDM2 interaction region, and mutation of this residue renders p53 highly sensitive to degradation and repression targeted by MDM2 (Unger et al. 1999) and abrogates the ability of p53 to be stabilized after irradiation of cells (Chehab et al. 1999). Because of these findings, we focused our efforts on identifying the p53 S20 kinase. By using a biochemical approach, we identified human CHK1 (hCHK1) and CHK2/hCds1 as two novel p53 S20 kinases that phosphorylate multiple DNA damage-inducible phosphorylation sites in the amino terminus of p53.

\section{Results}

hCHK1 cofractionates with a p53 S20 kinase

To search for the p53 S20 kinase(s), a biochemical fractionation approach was undertaken (Fig. 1). HeLa cell nuclear extracts were loaded onto a phosphocellulose P11 column and bound proteins were eluted in stepwise fashion with buffers containing $0.1,0.3,0.5$, and $0.85 \mathrm{M}$ $\mathrm{KCl}$. Phosphorylating activities were measured by in

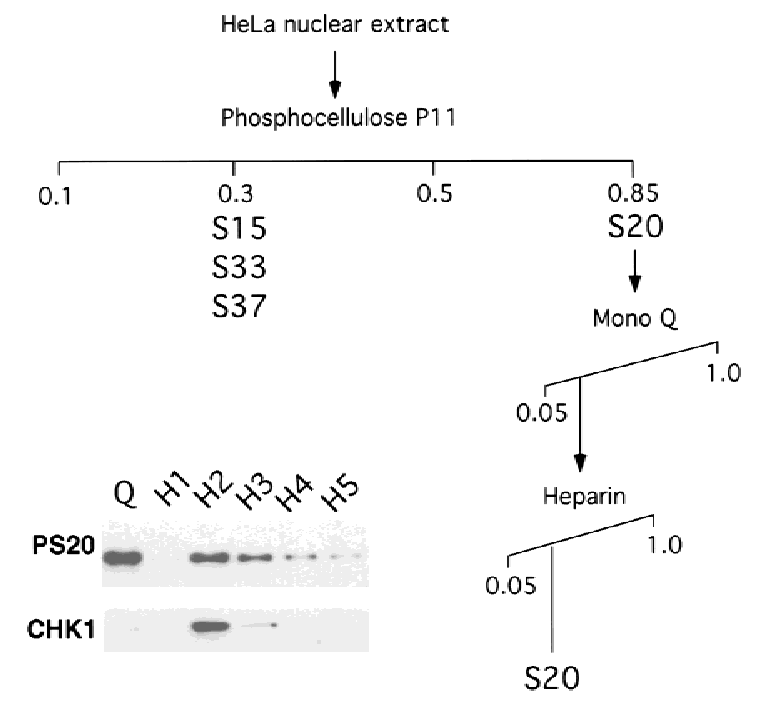

Figure 1. p53 S20 kinase cofractionates with hCHK1. HeLa cell nuclear extracts were fractionated first through a phosphocellulose P11 column. Aliquots from each fraction were taken and used in kinase assays followed by Western analyses with anti-phosphoserine antibodies directed against p53 phosphorylated at S15, S20, S33, and S37 to monitor the specific kinase activity. The P11 0.85 fraction was then passed through Mono-Q Sepharose and fractions that contained the S20 kinase activity were pooled and further fractionated through a heparin column. (Inset) (Western blot) shows the coelution of S20 kinase activity with hCHK1 in fractions eluting from the heparin column. 
vitro kinase assays with His-tagged p53 purified from bacteria (His-p53) as substrate, followed by SDS-PAGE and Western blotting with previously characterized antiphosphoserine-specific p53 antibodies as probes. The results indicated that the majority of the S15, S33, and S37 kinase activities were eluted with $0.3 \mathrm{M} \mathrm{KCl}$ (data not shown), whereas most of the S20 kinase activity was not eluted until the salt concentration was raised to $0.85 \mathrm{M}$ $\mathrm{KCl}$. Consistent with the elution profile, we detected all of the presently known p53 S15 kinases (DNA-PK, ATM, and ATR) in the $0.3 \mathrm{M} \mathrm{KCl}$ fraction (data not shown) by Western blotting after probing with the appropriate antibodies. To further purify the p53 S20 kinase(s), the $0.85 \mathrm{M} \mathrm{KCl}$ fraction was passed consecutively through Mono Q and heparin columns. S20 kinase activity was eluted at $\sim 0.1 \mathrm{M} \mathrm{KCl}$ from Mono Q, and was eluted from heparin with $\sim 0.3 \mathrm{M} \mathrm{KCl}$. In an attempt to match the activity with known kinases, especially those related to DNA damage checkpoint control, we discovered that the S20 kinase activity coeluted from the heparin column with hCHK1 (Fig. 1, inset). The presence of hCHK1 closely followed that of the S20 kinase activity: It is present in the peak fraction of Mono Q (not shown), and the peak fractions from the heparin column $(\mathrm{H} 2$, H3). Although the material eluting from the heparin column was probably not highly pure, the fact that the peak S20 kinase activity and Chk1 protein fractions coeluted supports the likelihood that the main, if not the sole, p53 S20 kinase activity in this fraction is Chk1.

Chk1 kinase has been shown to be a DNA damageresponsive cell cycle checkpoint protein and therefore, subsequent experiments were performed to extend these initial findings.

\section{Recombinant hCHK1 phosphorylates sites within the p53 amino terminus in vitro}

The $0.85 \mathrm{M} \mathrm{KCl}$ fraction that eluted from the phosphocellulose column did not contain detectable S15 kinase activity. Nevertheless, the partially purified S20 kinase eluting from the heparin column exhibited the ability to phosphorylate p53 at S15 as well (data not shown). Thus, either S15 and S20 kinases were copurified, or this fraction contains kinase(s) capable of phosphorylating both S15 and S20. To test the latter possibility and also to confirm that hCHK1 is a genuine S20 kinase, we expressed and purified GST-hCHK1 from baculovirus-infected insect cells. GST-CHK1 and chromatographically purified DNA-PK were compared for their ability to phosphorylate His-p53. The phosphorylation site(s) were then revealed by SDS-PAGE, followed by Western blot analysis with either anti-phospho-S15 or anti-phosphoS20 antibodies. As shown in Figure 2A, whereas purified DNA-PK phosphorylated His-p53 at S15 in a DNA-dependent manner, recombinant hCHK1 phosphorylated both S15 and S20 (Fig. 2A). Unlike phosphorylation by DNA-PK, phosphorylation of p53 by hCHK1 was not enhanced by DNA (Fig. 2B, cf. lanes 5 and 6), nor was it inhibited by the PI-3 kinase-specific inhibitor wortmannin (Fig. 2B, lanes 7-9). As both DNA-PK (for review, see Smith et al. 1999) or ATM (Banin et al. 1998) are strongly inhibited by the concentration of wortmannin that was used, this rules out contamination by either of these kinases. Contamination by ATR, another S15 kinase that is much less sensitive to wortmannin (Sarkaria 1998), was also excluded when the purified GST-hCHK1 was passed through a Superose 6 column. GST-hCHK1 was
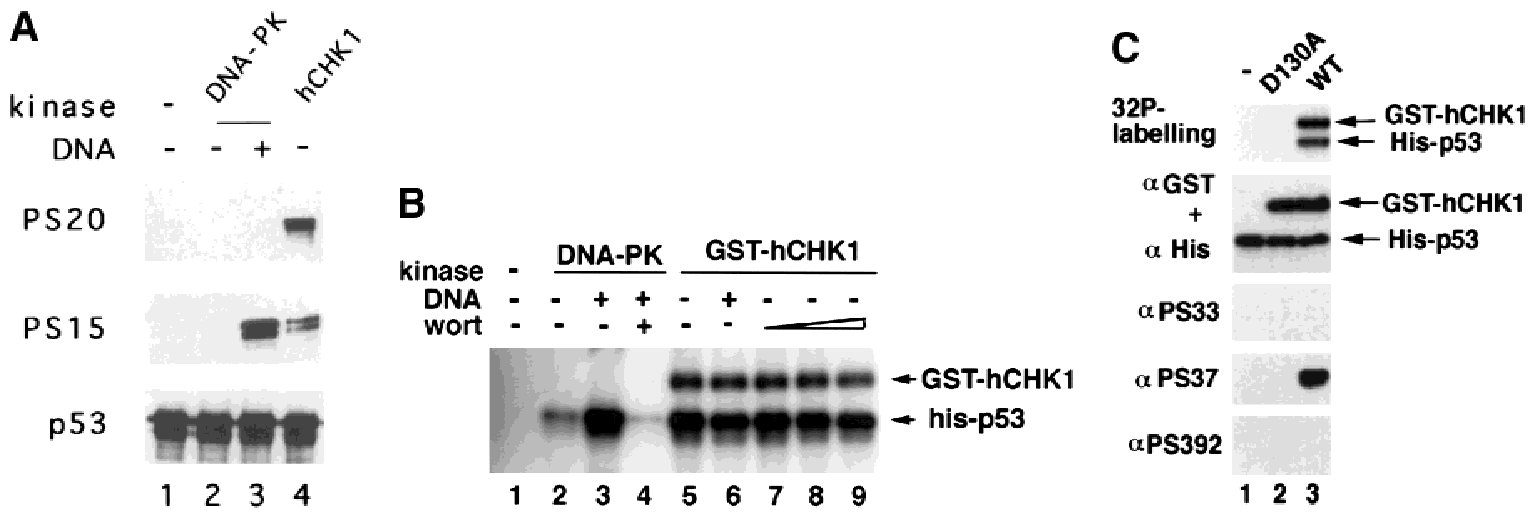

Figure 2. Recombinant hCHK1 phosphorylates p53 in vitro. (A) hCHK1 phosphorylates p53 at both S15 and S20, whereas DNA-PK targets S15 but not S20. His-tagged p53 prepared from bacteria was incubated alone, or with purified DNA-PK in the presence or absence of DNA as indicated, or with GST-hCHK1 in the absence of DNA. Phosphorylation of p53 was determined by Western blotting with respective anti-phospho-S15 and anti-phospho-S20 antibodies. The level of p53 in each reaction was then determined by stripping the blot and reprobing with an anti-His-tag antibody. $(B)$ The kinase activity of hCHK1 is not affected by DNA or wortmannin. Kinase assays were carried out as described above in the presence or absence of $100 \mathrm{ng}$ of DNA, and/or 0.5 $\mu \mathrm{M}$ (lanes 4,7), 1 $\mu \mathrm{M}$ (lane 8), or $2 \mu \mathrm{M}$ (lane 9) wortmannin. The mixtures were analyzed by SDS-PAGE, and the gel was dried and autoradiographed. (C) S37, but not S33 or S392, is phosphorylated by hCHK1. His-tagged p53 was incubated with wild-type (WT) or the kinase-defective mutant (D130A) of GST-hCHK1. The reactions were then analyzed by Western blotting with either anti-phospho-S33, S37, or S392 antibodies. Equal loading was demonstrated by reprobing the membrane with anti-His antibody, which recognizes p53, and anti-GST antibody, which recognizes hCHK1. 
eluted as a $150-\mathrm{kD}$ species, (most likely a dimer due to the GST moiety) and is thus significantly smaller than the predicted elution profile of the ATR protein (estimated molecular mass $301 \mathrm{kD})$. hCHK1 eluted from the Superose column also phosphorylated both S15 and S20 on p53 (data not shown), further supporting the likelihood that this kinase is a bona fide S20 kinase as well as a S15 kinase.

We then asked whether recombinant hCHK1 could phosphorylate additional sites within p53. By probing a blot containing p53 phosphorylated by hCHK1 with antibodies that recognize phospho-S33, phospho-S37, or phospho-S392, we found that hCHK1 also phosphorylates S37, but not S33 or S392 (Fig. 2C, lane 3). Note that the antibodies directed against phospho-S33 and phospho-S392 are each specific for, and also reactive with, p53 phosphorylated at these respective residues (Ko et al. 1998; Lu et al. 1998). As a control, a kinase-dead mutant of hCHK1, D130A (Sanchez et al. 1997), showed no detectable kinase activity (Fig. 2C, lane 2). These results demonstrate that hCHK1 is a versatile kinase that phosphorylates multiple serine residues in the amino-terminal domain of p53 in vitro.

Phosphorylation of the p53 amino terminus in vitro by hCHK1 requires the tetramerization domain

Previously, we discovered that whereas the amino terminus of p53 by itself (i.e., residues 1-96) cannot be phosphorylated at S15, S20, or S33 in vivo, phosphorylation at these three sites can occur if the amino terminus is fused to sequences containing the tetramerization domain (residues 299-363) (Shieh et al. 1999). Because two of these sites are substrates for hCHK1 in vitro, it was interesting to determine whether a similar prerequisite might exist for this protein kinase. To examine the structural requirements of p53 for phosphorylation by hCHK1, several truncated or internally deleted mutants of p53 were used. One mutant spanning amino acids
1-363 contains the tetramerization domain but lacks the very carboxy-terminal 30 amino acid basic region. Another mutant (1-307) lacks both the tetramerization and basic regions. These mutants were expressed, purified from bacteria, and used as substrates in in vitro hCHK1 kinase assays. Figure $3 \mathrm{~A}$ shows that the overall ${ }^{32} \mathrm{P}$ incorporation catalyzed by hCHK1 was strongly reduced in p53 (1-307), and phosphorylation of this version of p53 at S15 and S20 was also strongly diminished. This result suggested that tetramerization may be important for efficient phosphorylation of p53 by hCHK1. To further confirm that hCHK1 requires the tetramerization domain, we tested an HA-tagged p53 mutant (dlTD), which carries an internal deletion of amino acids 334-356 in the tetramerization domain and is incapable of oligomerization (Shaulian et al. 1993; Jayaraman et al. 1997). In contrast to that of the wild-type protein, phosphorylation of dlTD by hCHK1 on S15 and S20 was abolished (Fig. 3B, lanes 4, 5). Because these proteins were prepared from baculovirus-infected insect cells, basal phosphorylation was seen occasionally with the wild-type p53 (Fig. $3 \mathrm{~B}$, lane 1). In this case, however, neither S15 nor S20 phosphorylation was observed with the dlTD mutant, suggesting that dlTD is also a poor substrate for S15 and S20 kinases in vivo (Fig. 3B, lane 2). Taken together, these results demonstrate the importance of an intact tetramerization domain for $\mathrm{p} 53$ to be phosphorylated by hCHK1 in vitro.

\section{Modulation of hCHK1 expression affects p53 levels in vivo}

Because hCHK1 phosphorylates sites in the amino-terminal domain of p53 that are known to be inducibly phosphorylated after DNA damage, we tested the effects of regulating hCHK1 expression on p53. p53 was cotransfected with either a sense or antisense hCHK1 construct into the p53-null cell line H1299, and both p53 levels and S15 phosphorylation before and after $\gamma$ irradiation
Figure 3. Efficient phosphorylation of the p53 amino terminus by hCHK1 requires the tetramerization domain. (A) GST-hCHK1 was incubated with either Histagged wild-type (WT, lane 2) or truncated 1-363 (lane 3), 1-307 (lane 4) p53 proteins prepared from bacteria. Phosphorylation was visualized either by autoradiography or by Western blotting with anti-phospho-S15 or anti-phospho-S20 antibodies. Levels of p53 proteins were detected by reprobing the blot with the p53 monoclonal antibody PAb1801. (B) HA-tagged wildtype (WT) p53 or a deletion mutant dlTD, which carries an internal deletion in the tetramerization domain, was prepared from baculovirus-infected insect cells and incubated alone (lanes 1,2) or with GSThCHK1 (lanes 4,5). Phosphorylation was then determined as described in $A$.
A

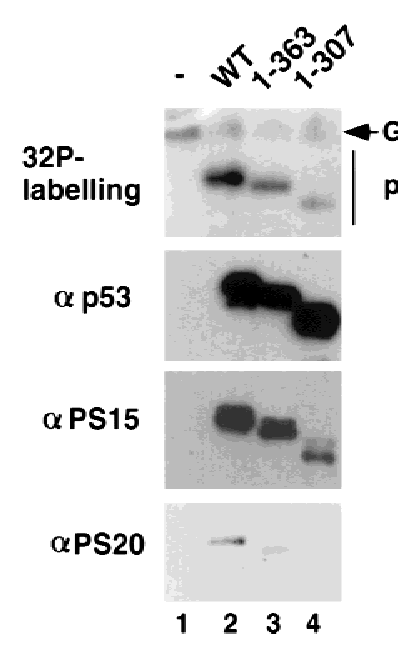

B

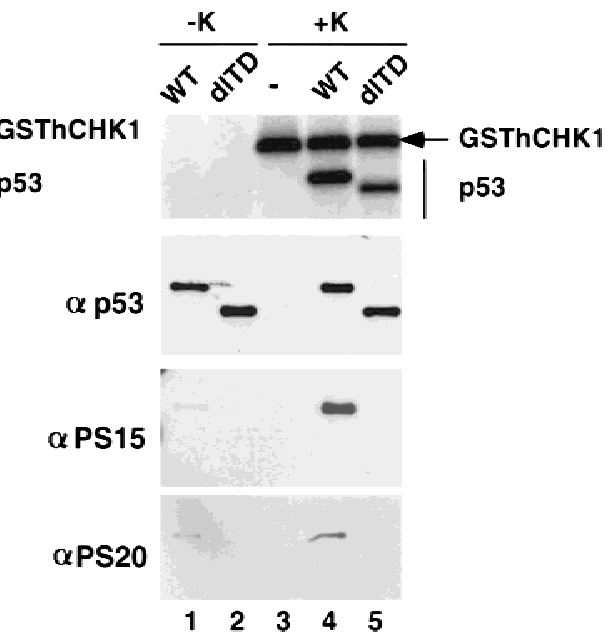


were determined. Although the sense hCHK1 construct had little effect on either phosphorylation or the level of transfected p53, the antisense hCHK1 construct (chk1AS) greatly reduced the p53 protein levels (Fig. 4A). Cotransfection of a sense construct expressing a kinasedead hCHK1 (D130A) had an intermediate effect, suggesting that the kinase-dead mutant may have a partially dominant-negative effect in vivo. S15 phosphorylation appeared to be roughly proportional to the overall levels of p53 protein. Although this could indicate that phosphorylation of this site per se is not affected by reducing the levels or activity of hCHK1, it is difficult to distinguish the cause and the consequence when both protein and phosphorylation are reduced. It is not unexpected that transfection of the sense hCHK-1 construct had no significant effect on p53 protein levels, because DNAdamaging agents do not appear to further stabilize transfected p53 in H1299 cells (Chen et al. 1996; N. Baptiste; P. Friedlander, X. Chen and C. Prives, unpubl.).

One clear drawback to the interpretation of our results in Figure $4 \mathrm{~A}$ is the fact that we have been unable to assess the level of endogenous Chk1 in cells expressing a Chk1 anti-sense construct. The polyclonal antibody that we raised against Chk1 performed well on partially purified Chk1 protein (see Fig. 1) and Chk1 protein in infected insect cell extracts (data not shown), but there were difficulties in detecting Chk1 in crude mammalian cell extracts, whether Chk1 was overexpressed or not. Nevertheless, the results shown in Figure 4A were highly reproducible among different experiments.

\section{A H1299}

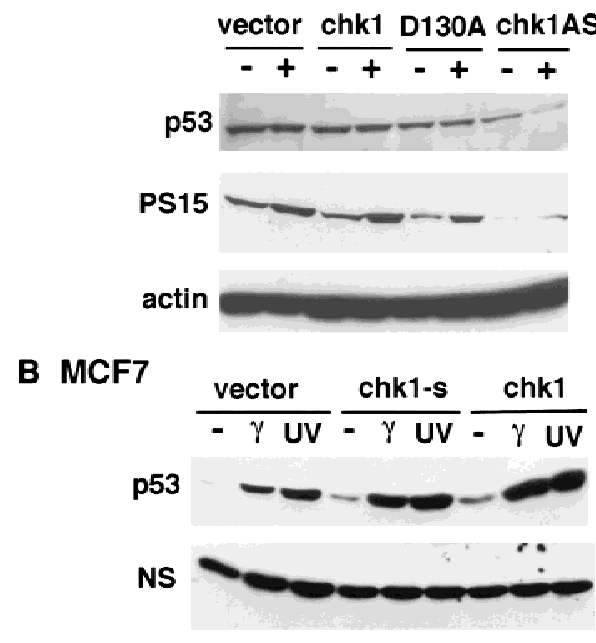

Figure 4. Modulation of hCHK1 affects p53 levels in vivo. (A) Down-regulation of hChk-1 p53 decreases p53 levels in vivo. Constructs expressing p53 and either wild- type hCHK1 (chk1), the kinase-dead hCHK1 mutant D130A, or antisense CHK1 (chk1AS) were transfected into p53-null H1299 cells. Cells were collected and lysed 36-40 hr after transfection and levels of p53 and phosphorylation at $\mathrm{S} 15$ were determined by Western blotting with PAb1801 and anti-phospho-S15 antibodies, respectively. (B) Overexpression of hCHK1 increases p53 levels in vivo. MCF7 cells were transfected with p53 together with either empty vector, a short form of hCHK1 that contains the amino-terminal kinase domain alone (chk1-s), or full-length hCHK1. Cells were treated $24 \mathrm{hr}$ after transfection with either $\gamma(7 \mathrm{~Gy})$ or UV $\left(50 \mathrm{~J} / \mathrm{m}^{2}\right)$ irradiation, and harvested $2 \mathrm{hr}$ and $5 \mathrm{hr}$ later, respectively. Levels of p53 were determined by Western blotting with antibodies PAb421 and PAb1801. A nonspecific (NS) band detected during the probing was used as a loading control. (C) Relative levels of p53 shown in $B$ (Exp 1) as well as two other experiments (Exp 2 and Exp 3) were quantified by densitometry.
C

\section{Exp. 1}

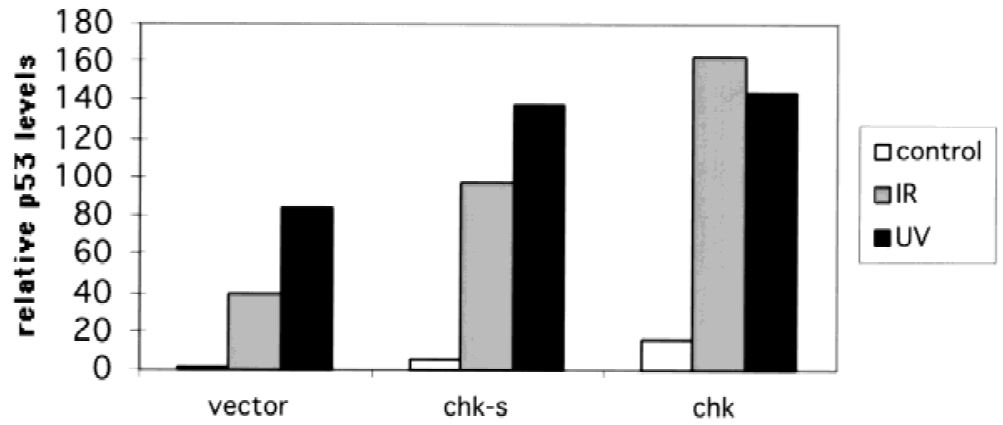

Exp. 2

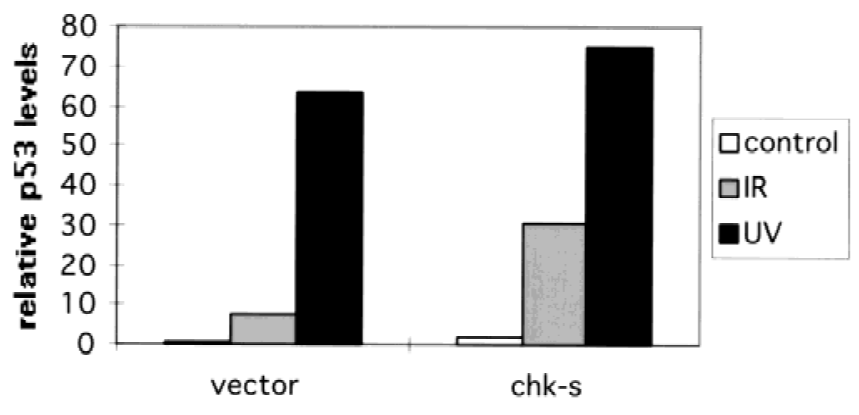

Exp. 3

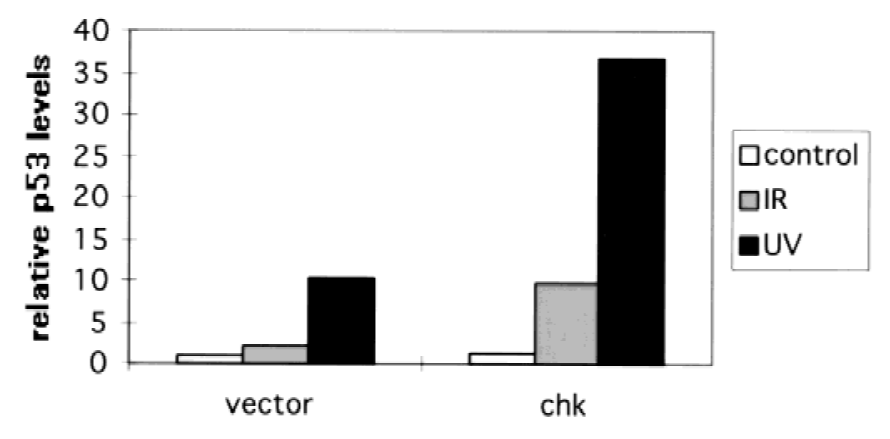


To test the effect of hCHK1 overexpression on endogenous p53, we also transfected the hCHK1 construct into MCF7 cells that contain endogenous wild-type p53. As shown in Figure 4B, overexpression of the hCHK1 kinase domain (chk1-s) both enhanced the basal levels of p53 (lanes) and also significantly augmented the extent to which p53 was increased after $\gamma$ irradiation. The effect of overexpression of this construct on UV-induced stabilization was less possibly reflecting the higher levels of p53 seen after UV when compared with $\gamma$ irradiation. The endogenous p53 levels were also markedly increased after IR when full-length hCHK1 (chk1) was transfected into the MCF7 cells. Three separate experiments in which the extent of p53 expression has been graphed are shown in Figure 4C. The fold effects of hCHK1 overexpression in each case are likely to be a significant underrepresentation of the actual effect, because the efficiency of transfection of MCF7 cells is on the order of $10 \%-$ $20 \%$. These results indicate that hCHK1 can play a role in regulating the levels of p53 in vivo.

\section{Additional hCHK1 phosphorylation site(s) in the p53 carboxy-terminal domain}

hCHK1 phosphorylates three sites within the p53 amino terminus, suggesting a rather promiscuous specificity for site recognition. Thus, it is possible that sites outside of the amino-terminal domain are also substrates for this kinase. To test this hypothesis, several truncated p53 mutants were generated and phosphorylation by hCHK1 was assessed. As shown in Figure 5A, amino-terminally

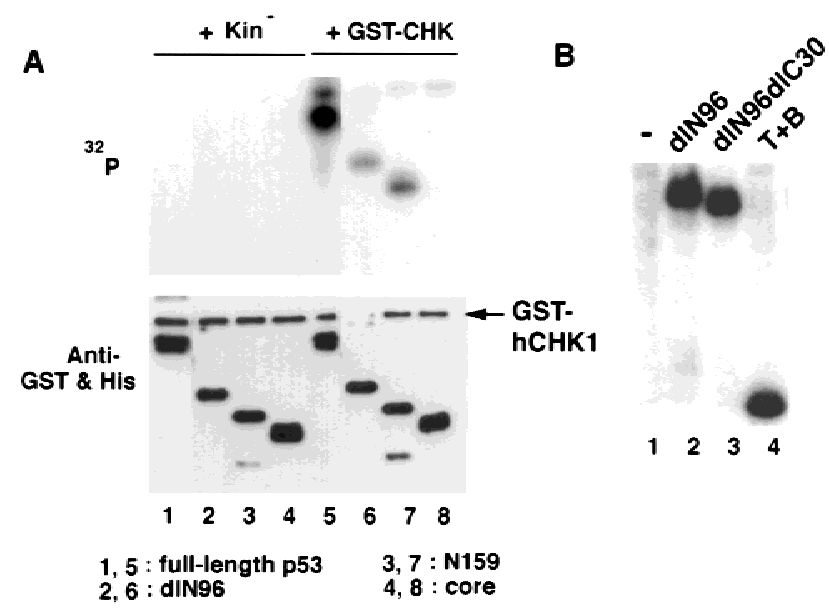

Figure 5. Additional hCHK1 phosphorylation site(s) in the p53 carboxy-terminal domain (A) GST-hCHK1 or kinase-defective GST-CHK1 proteins were incubated with either WT p53 or truncated p53 proteins as indicated. Phosphorylation was detected by autoradiography (top). The proteins were also transferred to a nitrocellulose membrane and detected by Western blotting with anti-GST antibody for detecting hCHK1 and antiHis for detecting p53 proteins (bottom). (B) Autoradiograph of a kinase assay done similarly as in $A$ with GST-CHK1 and $300 \mathrm{ng}$ of the indicated p53 proteins. (dlN96) Amino acids 97-393; (dlN96dlC30) amino acids 97-363; (core) amino acids 97-305; (T+B) amino acids 311-393; (N159) amino acids 1-159. deleted p53 (d1N96) could still be phosphorylated by hCHK1, although to a much lesser extent than fulllength p53. The amino-terminal 159 amino acids were also rather weakly phosphorylated, however, this might be due to the fact that this version of p53 lacks the tetramerization domain. The result with dlN96 showed that one or more sites elsewhere in p53 could be targets of Chk1. The core domain alone was not phosphorylated by hCHK1 (Fig. 5A), whereas the carboxy-terminal portion (residues 311-393) could be phosphorylated under the assay conditions (Fig. 5B). Interestingly, deletion of the carboxyl terminus in the context of $\Delta$ N96 (97-363, $\Delta \mathrm{N} \Delta \mathrm{C}$ ) displayed no difference in terms of phosphorylation when compared with deletion of the amino terminus alone (Fig. 5B). This result suggests that additional carboxy-terminal sites for hCHK1 do not reside in the carboxy-terminal 30 amino acids, even though this region contains a number of serines that can be phosphorylated by PK-C and CKII (Meek 1998). Furthermore, mutation of S315, a CDK site, along with three neighboring serine residues had no effect on phosphorylation of p53 by hCHK-1 (data not shown), suggesting that carboxyterminal hCHK1 site(s) may be novel and yet to be identified.

The human homolog of yeast cds1 phosphorylates p53 at sites similar to those of hCHK1

In fission yeast $S$. pombe, the DNA damage and replication checkpoints are regulated by Chk $1\left(\mathrm{G}_{2} / \mathrm{M}\right)$ and $\mathrm{Cds} 1$ (S) kinases (for review, see Elledge 1996; Weinert 1998). The human homolog of Cds1 (CHK2/hCds1) has been isolated (Matsuoka et al. 1998; Blasina et al. 1999; Brown et al. 1999; Chaturvedi et al. 1999) and shown to share similar substrate specificity as hCHK1 on Cdc25C (Matsuoka et al. 1998). To test whether this kinase can also phosphorylate p53, the CHK2/hCds1 cDNA was cloned by RT-PCR with RNA prepared from the prostate cancer cell line LNCaP. Baculoviruses expressing Flag-tagged wild-type $\mathrm{CHK} 2 / \mathrm{hCds} 1$ or a kinase-defective mutant kinase (D347A) were generated and tested for their ability to phosphorylate bacterially expressed p53 protein. As shown in Figure 6A (lanes 4,5) and Fig. 6B (lane 3), FlagCHK2/hCds1 phosphorylated p53 at S15, S20, and S37, but not S33 or S392. Interestingly, Flag-CHK2/hCds1 also phosphorylated T18, another potential phosphorylation site that lies within the MDM2 interaction domain (Fig. 6B). We have not yet determined whether hCHK1 can also phosphorylate T18. The kinase-defective mutant of Flag-CHK2/hCds1 (D347A) was not able to phosphorylate p53. Importantly, phosphorylation of p53 by CHK2/hCds1 is not due to contamination with another kinase, because a His-tagged version of CHK2/ hCds1 prepared from bacteria showed the same specificity (Fig. 6A, cf. lanes 2 and 4). We also tested the impact of tetramerization of p53 on its ability to be phosphorylated by his-CHK2/hCds1 (Fig. 6C,D). As had been observed with hCHK1, p53 lacking the tetramerization domain could not be phosphorylated at either S15 or S20. Thus, both hCHK kinases display similarities in the p53 
A

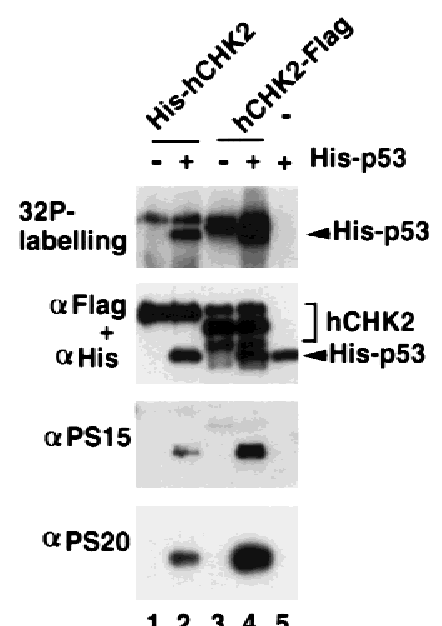

123345

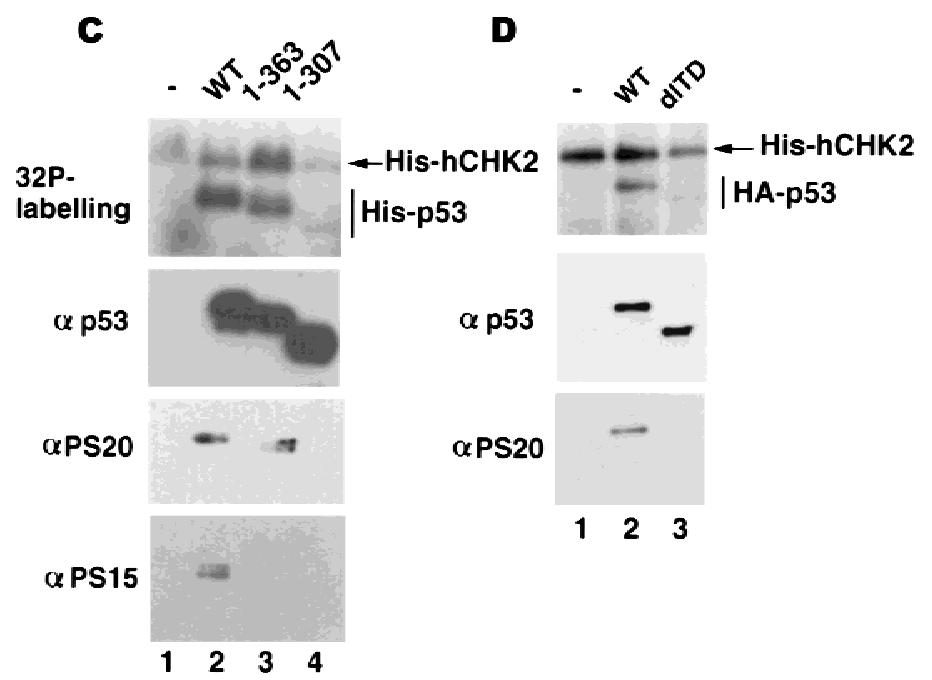

Figure 6. $\mathrm{CHK} 2 / \mathrm{hCds} 1$ phosphorylates p53 tetramers in vitro. (A) Phosphorylation of the p53 amino-terminal domain by CHK2 at S15 and S20 in vitro. His- and Flagtagged $\mathrm{CHK} 2 / \mathrm{hCds} 1$ prepared from bacteria or Flagtagged CHK2/Cds1 prepared from baculovirus-infected insect cells was incubated alone or with His-p53 and the resulting phosphorylation was assessed by autoradiography or by Western blotting with anti-phosphoserine-specific antibodies. (B) CHK2/hCds1 phosphorylates additional sites in the amino terminus of p53. Wild-type Flag-CHK2/hCds1 or a kinase-dead mutant (D347A) prepared from baculovirus-infected insect cells was used to phosphorylate p53, and the phosphorylation status of p53 was analyzed as described above. $(C)$ CHK2/hCds1 phosphorylates p53 tetramers but not monomers at S15 and S20. Flag-CHK2/Cds1 was incubated with either His-tagged wild-type (WT, lane 2), truncated 1-363 (lane 3), or 1-307 (lane 4) p53 proteins prepared from bacteria. Phosphorylation was visualized either by autoradiography $\left({ }^{32} \mathrm{P}\right.$ labeling) or by Western blotting with anti-phospho-S15 or anti-phospho-S20 antibodies. Levels of p53 proteins were detected by reprobing the blot with the p53 monoclonal antibody PAb1801. (D) HA-tagged wild-type (WT) p53 or the deletion mutant dlTD that lacks a functional tetramerization domain were incubated with bacterially expressed his-hCHK2 . Phosphorylation was then determined as described in $A$ and $C$. amino-terminal sites that they phosphorylate as well as their requirements for oligomerization of p53. However, we have evidence that there may be additional sites in the carboxyl terminus of p53 that are differentially phosphorylated by these two kinases, and which differ in their recognition and phosphorylation of other truncated versions of p53 (data not shown). For example, phosphorylation of the dlN96 mutant by $\mathrm{CHK} 2 / \mathrm{hCds} 1$ was markedly enhanced compared with the wild-type protein and other mutants. In addition, the N159 mutant, although phosphorylated by hCHK1, was a poor substrate for CHK2/hCds1. Therefore, despite all of the similarities, hCHK1 and CHK2/hCds1 appear to be divergent in recognizing certain regions of p53, and possibly CHK2/ hCds 1 is relatively more efficient in phosphorylating the p53 carboxyl terminus.

\section{Discussion}

We have demonstrated that the human homologs of the checkpoint kinases, CHK1 and CHK2/hCds1, phos- phorylate at least three DNA damage-inducible phosphorylation sites in p53. Our data suggest that both sequence and structural requirements of hCHK kinases for their substrates are complex and possibly novel. Modulation of hCHK1 levels and activity in vivo leads to changes in the accumulation of p53 protein. Taken together, our results suggest a new role for the mammalian CHK kinases in phosphorylation and regulation of p53.

It was unexpected that the hCHK kinases can phosphorylate several diverse sites in p53 including S20 or S15 and S37 and one or more as-yet-unidentified site(s). There are no obvious sequence motifs shared by these p53 sites or with the CHK kinase sites identified in CDC25. Thus, these kinases may be extremely flexible in their sequence requirements and substrate specificity. In this respect, they may resemble protein kinases such as GSK-3 in which phosphorylation of its sites requires prephosphorylation of neighboring sites (Fiol et al. 1987). However, GSK-3, requires a priming kinase, casein kinase II, whereas our data suggest that Chk kinases would provide their own priming function. Clearly, more work 
is needed to elucidate the sequence and structural requirements for phosphorylation of $\mathrm{p} 53$ by these kinases.

We have shown previously that p53 tetramerization is a prerequisite for efficient phosphorylation of the aminoterminal sites in vivo, in particular, S15, S20, and S33 (Shieh et al. 1999). In this report we demonstrate that recombinant hCHK1 and $\mathrm{CHK} 2 / \mathrm{hCd} 1$ proteins possess similar requirements for phosphorylation of p53 as do in vivo p53 amino-terminal kinases. Tetramerization may provide a preferable conformation for substrate recognition, or the domain may serve as a kinase docking site. The unusual requirement for p53 tetramerization for efficient phosphorylation in vitro by hCHK kinases provides support for the possibility that they do phosphorylate p53 in vivo.

Although DNA damage induces phosphorylation of p53 at sites within its amino terminus and carboxyl terminus, the consequence of such phosphorylation events remains to be elucidated. Different studies have provided essentially conflicting results: Mutation of several serine residues, either alone or in combination, was reported not to significantly affect stabilization of transfected p53 by either $\gamma$ or UV irradiation or actinomycin D (Ashcroft et al. 1999; Blattner et al. 1999). However, mutation of S20 alone renders p53 more sensitive to MDM2 repression and degradation (Unger et al. 1999) and reduces its ability to be stabilized after irradiation (Chehab et al. 1999). Thus, the possible role of phosphorylation in p53 stabilization is as yet not well understood. We show here that hCHK1, when overexpressed, enhances the levels of p53 before and after ionizing radiation in transient transfection experiments (Fig. 4B). Furthermore, overexpression of antisense hCHK1 significantly decreases the level of cotransfected p53 (Fig. 4A). Halazonetis and colleagues have made similar observations about CHK2/ hCds1 and p53 (Chehab et al. 2000). These observations can be interpreted in at least two ways. One is that hCHK1 and CHK2/hCds1 phosphorylate p53 directly in vivo and, as a result, stabilize p53. If this is the case, the site(s) responsible for the stabilizing effect may not be those that we identified at the amino terminus of the protein. Instead, the effect may be mediated via other yet-to-be identified sites. Using in vitro kinase assays, we have evidence for additional hCHK1 sites in a region on p53 between amino acids 304 and 363, excluding the cdk sites. Identifying these sites might resolve the issue regarding the relationship between phosphorylation and p53 stabilization. Alternatively, the stabilizing effect may not be direct, but is mediated through phosphorylation of other proteins. It is noteworthy that DNA-PK phosphorylates the oncoprotein MDM2, and such phosphorylation disrupts its interaction with p53 (Mayo et al. 1997). Additionally, ATM can phosphorylate MDM2 in vitro, and this leads to reduced interaction with p53 (Khosravi et al. 1999). Finally, we have found that MDM2 can be phosphorylated by hCHK1 in vitro, although the sites that it phosphorylates are not as yet identified (T. Zhang, S-Y. Shieh, and C. Prives, unpubl.). Phosphorylation of MDM2 or other p53-interacting proteins may be a necessary feature of p53 stabilization.
The relationship between Chk1 and cell cycle checkpoints has been well studied in fission yeast. Yeast Chk1 mediates the checkpoint control elicited by DNA damage (Walworth et al. 1993). The task is thought to be accomplished via phosphorylation of Cdc25, a phosphatase that regulates the activity of Cdc2 (Furnari et al. 1997; Peng et al. 1997; Zeng et al. 1998). Phosphorylated Cdc25 protein was found to bind 14-3-3 proteins more readily (Peng et al. 1997; Zeng et al. 1998), and this may change Cdc25 activity (Furnari et al. 1999) or cellular localization (Lopez-Girona et al. 1999). The function of yeast Chk1 requires an upstream kinase $\operatorname{Rad} 3$, a PI-3 kinase family member, which shares extensive homology with mammalian ATM and ATR. Overexpression of yeast Chk1 complements the $\mathrm{G}_{2} / \mathrm{M}$ checkpoint defect in AT cells (Chen et al. 1999). However, hCHK1 was reported to be expressed and active in ATM-deficient cells (Kaneko et al. 1999), suggesting that ATM and hCHK1 may not necessarily have an exclusive upstream-downstream relationship in mammals, as they do in yeast. hCHK1 may sense different signals through multiple upstream kinases. Likewise, the signals received by ATM may be transferred to multiple, complementing kinases. In support of this notion, $\mathrm{CHK} 2 / \mathrm{hCds} 1$, the homolog of budding yeast Rad53 and fission yeast Cds1, was found to act downstream of ATM in mediating the DNA damage checkpoint (Matsuoka et al. 1998; Brown et al. 1999; Chaturvedi et al. 1999). Furthermore, we have shown in this report that $\mathrm{CHK} 2 / \mathrm{hCds} 1$ phosphorylates p53 amino terminus at similar sites as hCHK1. Because both kinases phosphorylate p53 at overlapping sites, more studies will be needed to determine the relative contribution of each kinase with respect to the p53 DNA damage response.

It is perfectly possible that although both hCHK1 and CHK2/hCds1 respond to $\gamma$ and UV treatment, each may function at different cell cycle stages. hCHK1 was shown to be activated only between the $S$ and $M$ phases of the cell cycle (Kaneko et al. 1999). In fission yeast, $\gamma$ IR activates Cds1, the yeast CHK2 homolog, only during S phase (Lindsay et al. 1998). However, CHK2/hCds1 can respond to DNA damage throughout the cell cycle (Matsuoka et al. 1998). There is evidence for cross talk between the two kinases: Yeast Cds1, when activated, inhibits the activity of Chk1 (Brondello et al. 1999) and although as yet untested, CHK2/hCds1 may similarly be able to regulate the function of hCHK1 under some conditions. Alternatively, they may function in parallel and each may be able to complement the other in vivo. The future challenge will be to determine the relative contribution of these two kinases in vivo and how they regulate $\mathrm{p} 53$. The fact that mutations in hCHK1 (Bertoni et al. 1999) and hCHK2 (Bell et al. 1999) have been identified in human cancer patients lends support to the importance of this goal.

\section{Materials and methods}

Cell lines and transfections

H1299 (human non-small-cell lung carcinoma) and MCF7 cells 
(human mammary carcinoma) cells from ATCC were maintained in RPMI and DMEM, respectively, supplemented with $10 \%$ FBS. For transfection, H1299 cells were plated at $1.3 \times 10^{5} /$ $60-\mathrm{mm}$ dish the day before transfection and transfected by the calcium phosphate method. MCF7 cells were plated at $3 \times 10^{5} /$ $60-\mathrm{mm}$ dish and transfected with lipofectin reagent (GIBCOBRL). Cells were collected 36-40 hr after transfection and lysed in $1.5 \times$ SDS gel loading buffer [0.25 $\mathrm{m}$ Tris $(\mathrm{pH} 6.8), 1 \mathrm{~m} \beta$-mercaptoethanol, $6 \%$ SDS, $15 \%$ glycerol, $0.05 \%$ bromophenol blue], and analyzed on a 10\% SDS-polyacrylamide gel.

\section{Nuclear extract fractionation}

HeLa cell nuclear extracts $\left(\sim 1 \times 10^{9}\right.$ cells $)$ were prepared according to the procedure of Dignam et al. (1983) and fractionated through a phosphocellulose P11 column (Whatman) in buffer containing $20 \mathrm{~mm}$ Tris $\mathrm{HCl}(\mathrm{pH} 8.0), 0.2 \mathrm{~mm}$ EDTA, $0.1 \mathrm{M} \mathrm{KCl}$, $20 \%$ glycerol, $0.5 \mathrm{~mm}$ DTT, and $0.5 \mathrm{~mm}$ PMSF. Bound proteins were eluted sequentially with a step gradient of $0.3,0.5$, and $0.85 \mathrm{M} \mathrm{KCl}$ in the same buffer. Aliquots of each fraction were used in kinase assays with bacterially expressed His-tagged p53 as substrate. Western blot analyses were then performed with phosphoserine-specific antibodies as probes. Fractions that contain S20 kinase activity were pooled and further fractionated through a Mono Q column followed by a heparin column. Bound proteins were eluted with a salt gradient of $0.05-1 \mathrm{M} \mathrm{KCl}$. The S20 kinase activity was found to be eluted at $\sim 0.1$ and 0.3 $\mathrm{M} \mathrm{KCl}$ from Mono Q and heparin columns, respectively.

\section{Western blot analysis}

After SDS-PAGE, proteins were transferred to a nitrocellulose membrane. The membrane was blocked in PBS containing $0.05 \%$ Tween 20 and $1 \%$ nonfat dry milk for $30 \mathrm{~min}$ and probed in the same buffer with 250-fold-diluted anti-phosphoserine antibody as specified in the figure legends. Signals were visualized with chemiluminescent reagents (Pierce).

\section{Plasmid construction}

The cDNA for hCHK1 was obtained by RT-PCR with RNA prepared from LNCaP cells using as the $5^{\prime}$ primer: $5^{\prime}$-GATCTCGAGCATGGCAGTGCCCTTTGTG- $3^{\prime}$ that contains a XhoI site, and as the $3^{\prime}$ primer: 5'ATGGTACCTCAAGCGTAGTCTGGGACGTCGTATGGGTATGTGGCAGGAAGCCAAAC$3^{\prime}$ that carries a KpnI site and encodes an HA tag. The cDNA was then cloned into the XhoI and KpnI sites of the Bluescript plasmid (Stratagene). A similar strategy was used in cloning the hCHK2 gene, except that instead of an HA tag, a sequence encoding a Flag tag was incorporated into the $3^{\prime}$ primer. The two primers used for amplification of CHK2 are: 5'-GATCTCGAGGTCATGTCTCGGGAGTCG-3' and 5'-CATGGTACCTCACTTATCGTCATCGTCTTTGTAATCCAACACAGCAGCACA-3'. For expression in mammalian cells, both cDNAs were released from Bluescript by HindIII and KpnI cleavage, and recloned into the pHOOK-2 vector (Invitrogen). CHK2 cDNA was also cloned into the $\mathrm{XhoI} / \mathrm{KpnI}$ sites of pRSET A (Invitrogen) and pFastBac1 (GIBCO-BRL) for bacterial and baculoviral expression, respectively. PCR-based mutagenesis was used to create the CHK2D347A mutant. Amplified sequences were confirmed by DNA sequencing.

The plasmid for bacterial expression of His-p53/1-307 was generated by removing a Cac8I/EcoRI fragment from the parental pRSETp53 plasmid (Ko et al. 1997). The cDNAs for HisdlC30 (1-363), His-dlN96 (97-393), and core (97-305) were generated by PCR and cloned into KpnI and HindIII sites in pRSET
B (Invitrogen). His-N159 was generated by cleavage at the unique NcoI site and cloned into the PstI site in pRSET B. The plasmid for His-dlN96dlC30 was made by replacing the StuIHindIII fragment of dlN96 with the StuI-HindIII fragment of dlC30. The carboxy-terminal fragment spanning residues 311$393(\mathrm{~T}+\mathrm{B})$ was a gift from N. Pavletich (Memorial Sloan Kettering Cancer Center, New York) and has been described previously (Ko et al. 1997).

\section{Expression and purification of recombinant proteins}

For expression of His-p53 and its derivatives, pRSET plasmids with either full-length or truncated p53 cDNA were introduced into bacteria BL21(DE3)LysE. Overnight culture was diluted and grown to $\mathrm{OD}_{600}-0.5$. The culture was then induced with 1 $\mathrm{mm}$ isopropyl $\beta$-D-thiogalactopyranoside (IPTG), and incubated at $25^{\circ} \mathrm{C}$ for $2 \mathrm{hr}$. Cells were collected and lysed in sonication buffer $\left(0.3 \mathrm{M} \mathrm{NaCl}, 50 \mathrm{~mm} \mathrm{NaH}_{2} \mathrm{PO}_{4} \mathrm{pH} 8.0,20 \%\right.$ glycerol, $1 \%$ NP-40, 10 mM $\beta$-mercaptoethanol, 0.5 mM PMSF) by one cycle of freezing and thawing followed by brief sonication. Cell debris was removed by centrifugation and the supernatant was loaded onto a Ni-NTA column (Qiagen). The column was washed with $40 \mathrm{~mm}$ imidazole in sonication buffer without NP-40, and the bound protein was eluted with $0.25 \mathrm{M}$ imidazole. The eluted protein was then dialyzed in buffer containing $20 \mathrm{~mm}$ Tris $(\mathrm{pH}$ 8.0), $0.2 \mathrm{~mm}$ EDTA, 20\% glycerol, $0.5 \mathrm{~mm}$ DTT, and $0.5 \mathrm{~mm}$ PMSF for $30 \mathrm{~min}$, aliquoted, and stored at $-80^{\circ} \mathrm{C}$.

Baculoviruses expressing Flag-CHK2/hCds1 and the corresponding D347A mutant were created by the FASTBAC system (GIBCO-BRL) with Sf9 insect cells. GST-CHK1 and GST-Kin(D130A) were kind gifts of Y. Sanchez and S. Elledge (Baylor College of Medicine, Houston, TX). For large-scale infection, Sf9 cells were plated on $150-\mathrm{mm}$ culture dishes $1 \mathrm{hr}$ before infection, and cells were harvested $\sim 40 \mathrm{hr}$ after infection. Cell extracts were prepared by lysing the cells in C buffer $(50 \mathrm{~mm}$ Tris at $\mathrm{pH} 8.0,150 \mathrm{~mm} \mathrm{NaCl}, 1 \% \mathrm{NP}-40,0.1 \%$ aprotinin, 1 mM DTT, $0.5 \mathrm{~mm}$ PMSF). For purification of the HA-WTp53 and dlTD mutant proteins, lysates were incubated with mAb $12 \mathrm{CA} 5$ cross-linked to protein A beads overnight, and the bound proteins were eluted with the corresponding peptide as described previously (Jayaraman et al. 1997). Flag-CHK2/Cds1 and the D347A mutant were purified in a similar fashion, except that M2-agarose beads (Sigma) and the M2 peptide (Sigma) were used. For purification of GST-CHK1, the lysate was incubated with glutathione-Sepharose beads (Pharmacia) at $4^{\circ} \mathrm{C}$ for $1 \mathrm{hr}$, and the bound protein was eluted with reduced glutathione. For some experiments, GST-CHK1 was further purified through a Superose 6 column (Pharmacia) to ensure separation of hCHK1 from high molecular weight p53 S15 kinases.

\section{Generation of anti-hCHK1 antiserum}

GST-CHK1 prepared from baculovirus-infected insect cells and purified through a glutathione-Sepharose column (Pharmacia) was used to raise antibodies in rabbits (Cocalico Biologicals, Philadelphia, PA). Serum obtained after the second boost was purified on protein G Sepharose (Pharmacia), and diluted 1000fold for Western blot analysis.

\section{In vivo kinase assays}

The DNA-PK kinase assay was performed as described previously (Shieh et al. 1997). hCHK1 or CHK2/hCds1 kinase reaction mixtures $(20 \mu \mathrm{l})$ contained $300 \mathrm{ng}$ of the kinase, $500 \mathrm{ng}$ of His-p53 or 200 ng of HA-p53 in $1 \times$ kinase buffer $(20 \mathrm{~mm}$ Tris at $\mathrm{pH} 7.5,10 \mathrm{~mm} \mathrm{MgCl}_{2}, 2 \mathrm{~mm} \mathrm{MnCl} 2,1 \mathrm{~mm}$ DTT) in the presence 
of $25 \mu \mathrm{M}$ ATP and $5 \mu \mathrm{Ci}\left[\gamma-{ }^{32} \mathrm{P}\right]$ ATP. The mixtures were incubated at $30^{\circ} \mathrm{C}$ for $20 \mathrm{~min}$ and the reactions stopped by addition of an equal volume of $3 \times$ SDS gel loading buffer. The proteins were resolved by SDS-PAGE followed either by Western blot analysis or autoradiography.

\section{Acknowledgments}

We are grateful for the expert technical assistance of Ella Freulich. Vanesa Gottifredi is thanked for helpful suggestions and discussions. We thank Thanos Halazonetis for discussions and preliminary communication of his results with hCHK2/ Cds1 and p53. Gifts of antibodies directed against ATM and ATR from Y. Shiloh and R. Abraham, respectively, are greatly appreciated. This work was supported by NIH grant CA58316 to C.P. and Grants-in-Aid for Cancer Research for the 2nd Term Comprehensive 10-Year Strategy for Cancer Control, the Ministry of Health and Welfare, Japan and Research Grant of the Princess Takamatsu Cancer Research Fund to Y.T.

The publication costs of this article were defrayed in part by payment of page charges. This article must therefore be hereby marked "advertisement" in accordance with 18 USC section 1734 solely to indicate this fact.

\section{References}

Adler, V., M.R. Pincus, T. Minamoto, S.Y. Fuchs, M.J. Bluth, P.W. Brandt-Rauf, F.K. Friedman, R.C. Robinson, J.M. Chen, X.W. Wang et al. 1997. Conformation-dependent phosphorylation of p53. Proc. Natl. Acad. Sci. 94: 1686-1691.

Agarwal, M.L., W.R. Taylor, M.V. Chernov, O.B. Chernova, and G.R. Stark. 1998. The p53 network. J. Biol. Chem. 273: 1-4.

Ashcroft, M., M.H.G. Kubbutat, and K.H. Vousden. 1999. Regulation of p53 function and stability by phosphorylation. Mol. Cell. Biol. 19: 1751-1758.

Banin, S., S. Moyal, S.-Y. Shieh, Y. Taya, C.W. Anderson, L. Chessa, N.I. Smorodinsky, C. Prives, Y. Reiss, Y. Shiloh, and Y. Ziv. 1998. Enhanced phosphorylation of p53 by ATM in response to DNA damage. Science 281: 1674-1677.

Baudier, J., C. Delphin, D. Grunwald, S. Khochbin, and J.J. Lawrence. 1992. Characterization of the tumor suppressor protein p53 as a protein kinase C substrate and a S100bbinding protein. Proc. Natl. Acad. Sci. 89: 11627-11631.

Bell, D.W., J.M. Varley, T.E. Szydlo, D.H. Kang, D.C.R. Wahrer, K.E. Shannon, M. Lubratovitch, S.J. Verselis, K.J. Isselbacher, J.F. Fraumeni et al. 1999. Heterozygous germline hCHK2 mutations in Li-Fraumeni Syndrome. Science 286: 2528 2531.

Bertoni, F., A.M. Codegoni, D. Furlan, M.G. Tibiletti, C. Capella, and M. Broggini. 1999. CHK1 frameshift mutations in genetically unstable colorectal and endometrial cancers. Genes Chromosomes Cancer 26: 176-180.

Blades, J.P. and T. Hupp. 1998. DNA damage triggers DRB-resistant phosphorylation of p53 at the CKII site. Oncogene 17: 1045-1052.

Blasina, A., I.Z. deQeyer, M.C. Laus, W.H.M.L. Luyten, A.E. Parker, and C.H. McGowan. 1999. A human homologue of the checkpoint kinase Cds1 directly inhibits Cdc25 phosphoatase. Curr. Biol. 9: 1-10.

Blattner, C., E. Tobiasch, M. Litfen, H.J. Rahmsdorf, and P. Herrlich. 1999. DNA damage induced p53 stabilization: No indication for an involvement of p53 phosphorylation. Oncogene 18: 1723-1732.

Brondello, J.-M., M.N. Boddy, B. Furnari, and P. Russell. 1999.
Basis for the checkpoint signal specificity that regulates Chk1 and Cds1 protein kinases. Mol. Cell. Biol. 19: 42634269.

Brown, A.L., C.-H. Lee, J.K. Schwarz, N. Mitiku, H. PiwnicaWorms, and J.H. Chung. 1999. A human Cds1-related kinase that functions downstream of ATM protein in the cellular response to DNA damage. Proc. Nat1. Acad. Sci. 96: 37453750.

Canman, C.E., D.-S. Lim, K.A. Cimprich, Y. Taya, K. Tamai, K. Sakaguchi, E. Appella, M.B. Kastan, and J.D. Siliciano. 1998. Activation of the ATM kinase by ionizing radiation and phosphorylation of p53. Science 281: 1677-1679.

Chaturvedi, P., W.K. Eng, Y. Zhu, M.R. Mattern, R. Mishra, M.R. Hurle, X. Zhang, R.S. Annan, Q. Lu, L.F. Faucette et al. 1999. Mammalian Chk2 is a downstream effector of the ATM-dependent DNA damage checkpoint pathway. Oncogene 18: 4047-4054.

Chehab, N.H., A. Malikzay, M. Appel, and T.D. Halazonetis. 1999. CHk2/hCds1 functions as a DNA damage checkpoint in $\mathrm{G}^{1}$ by stabilizing p53. 2000. Genes \& Dev. (this issue)

Chehab, N.H., A. Malikzay, E.S. Stavridi, and T.D. Halazonetis. 1999. Phosphorylation of Ser20 mediates stabilization of human p53 in response to DNA damage. Proc. Natl. Acad. Sci. 96: $13777-13782$.

Chen, P., M. Gatei, M.J. O'Connell, K.K. Khanna, S.J. Bugg, A. Hogg, S.P. Scott, K. Hobson, and M.F. Lavin. 1999. Chk1 complementsthe G2/M checkpoint defect and radiosensitivity of ataxia-telangiectasia cells. Oncogene 18: 249-256.

Cuddihy, A.R., A.H.-T. Wong, N.W.N. Tam, S. Li, and A.E. Koromilas. 1999. The double-stranded RNA activated protein kinase PKR physically associates with the tumor suppressor p53 protein and phosphorylates human p53 on serine 392 in vivo. Oncogene 18: 2690-2702.

Dignam, J.D., P.L. Martin, B.S. Shastry, and R.G. Roeder. 1983. Eukaryotic gene transcription with purified components. Methods Enzymol.101: 582-598.

El-Deiry, W.S. 1998. Regulation of p53 downstream genes. Semin. Cancer Biol. 8: 345-357.

Elledge, S.J. 1996. Cell cycle checkpoints: Preventing an identity crisis. Science 274: 1664-1672.

Fiol, C.J., A.M. Mahrenholz, Y. Wang, R.W. Roeske, and P.J. Roach. 1987. Formation of protein kinase recognition sites by covalent modification of the substrate. Molecular mechanism for the synergistic action of casein kinase II and glycogen synthase kinase 3. J. Biol. Chem. 262: 14042-14048.

Flaggs, G., A.W. Plug, K.M. Dunks, K.E. Mundt, J.C. Ford, M.R.E. Quiggle, E.M. Taylor, C.H. Westphal, T. Ashley, M.F. Hoekstra, and A.M. Carr. 1997. Atm-dependent interactions of a mammalian Chk1 homolog with meiotic chromosomes. Curr. Biol. 7: 977-986.

Furnari, B., N. Rhind, and P. Russell. 1997. Cde25 mitotic inducer targeted by Chk1 DNA damage checkpoint kinase. Science 277: 1495-1497.

Furnari, B., A. Blasina, M.N. Boddy, C.H. McGowan, and P. Russell. 1999. Cdc25 inhibited in vivo and in vivo by checkpoint kinases Cds1 and Chk1. Mol. Biol. Cell 10: 833-845.

Giaccia, A.J. and M.B. Kastan. 1998. The complexity of p53 modulation: Emerging patterns from divergent signals. Genes \& Dev. 12: 2973-2983.

Haupt, Y., R. Maya, A. Kazaz, and M. Oren. 1997. Mdm2 promotes the rapid degradation of p53. Nature 387: 296-299.

Hu, M.C., W.R. Qiu, and Y.P. Wang. 1997. JNK1, JNK2, and JNK3 are p53 $\mathrm{N}$-terminal serine 34 kinases. Oncogene 15: 2277-2287.

Hupp, T.R. and D.P. Lane. 1994. Regulation of the cryptic sequence-specific DNA-binding function of p53 by protein ki- 
nases. Cold Spring Harbor Symp. Quant. Biol. 59: 195-206.

Hupp, T.R., D.W. Meek, C.A. Midgley, and D.P. Lane. 1992. Regulation of the specific DNA binding function of p53. Cell 71: 875-886.

Jamal, S. and E.B. Ziff. 1995. Raf phosphorylates p53 in vivo and potentiates p53-dependent transcriptional transactivation in vivo. Oncogene 10: 2095-2101.

Jayaraman, L., E. Freulich, and C. Prives. 1997. Functional dissection of the p53 tumor suppressor protein. Meth. Enzymol. 283: 245-256.

Kaneko, Y., N. Watanabe, H. Morisaki, H. Akita, A. Fujimoto, K. Tominaga, M. Terasawa, A. Tachibana, K. Ikeda, and M. Nakanishi. 1999. Cell cycle-dependent and ATM-independent expression of human Chk1 kinase. Oncogene 18: 3673 3681.

Kapoor, M. and G. Lozano. 1998. Functional activation of p53 via phosphorylation following DNA damage by UV but not by $\gamma$ radiation. Proc. Nat1. Acad. Sci. 95: 2834-2837.

Kastan, M.B., Q. Zhan, W.S. El-Deiry, F. Carrier, T. Jacks, W.V. Walsh, B.S. Plunkett, B. Vogelstein, and A.J. Fornace, Jr. 1992. A mammalian cell cycle checkpoint pathway utilizing p53 and Gadd45 is defective in Ataxia-telangiectasia. Cell 71: 587-597.

Khanna, K.K., K.E. Keating, S. Kozlov, S. Scott, M. Gatei, K. Hobson, Y. Taya, B. Gabrielli, D. Chan, S.P. Lees-Miller, and M.F. Lavin. 1998. ATM associates with and phosphorylates p53: Mapping the region of interaction. Nat. Genet. 20: 398 400.

Khosravi, R., R. Maya, T. Gottlieb, M. Oren, Y. Shiloh, and D. Shkedy. 1999. Rapid ATM-dependent phosphorylation of MDM2 precedes p53 accumulation in response to DNA damage. Proc. Natl. Acad. Sci. 96: 14973-14977.

Ko, L.J., S.-Y. Shieh, X. Chen, L. Jayaraman, K. Tamai, Y. Taya, C. Prives, and Z.-Q. Pan. 1997. p53 is phosphorylated by DNK7-cyclin $\mathrm{H}$ in a p36MAT1-dependent manner. Mol. Cell. Biol. 17: 7220-7229.

Kubbutat, M.H.G., S.N. Jones, and K.H. Vousden. 1997. Regulation of p53 stability by Mdm2. Nature 387: 299-303.

Lavin, M.F. and Y. Shiloh. 1997. The genetic defect in ataxiatelangiectasia. Annu. Rev. Immunol. 15: 177-202.

Lees-Miller, S.P., Y.-R. Chen, and C.W. Anderson. 1990. Human cells contain a DNA-activated protein kinase that phosphorylates simian virus $40 \mathrm{~T}$ antigen, mouse p53, and the human Ku autoantigen. Mol. Cell. Biol. 10: 6472-6481.

Levine, A.J. 1997. p53, the cellular gatekeeper for growth and division. Cell 88: 323-331.

Lindsay, G.D., D.J.F. Griffiths, R.J. Edwards, P.U. Christensen, J.M. Murray, F. Osman, N. Walworth, and A.M. Carr. 1998. S-phase-specific activation of Cds1 kinase defines a subpathway of the checkpoint response in Schizosaccharomyces pombe. Genes \& Dev. 12: 382-395.

Lohrum, M. and D.H. Scheidtmann. 1996. Differential effects of phosphorylation of rat p53 on transactivation of promoters derived from different p53 responsive genes. Oncogene 13: $2527-2539$.

Lopez-Girona, A., B. Furnari, O. Mondesert, and P. Russell. 1999. Nuclear localization of Cdc25 is regulated by DNA damage and a 14-3-3 protein. Nature 397: 172-175.

Lu, H., Y. Taya, M. Ikeda, and A.J. Levine. 1998. Ultraviolet radiation, but not $\gamma$ radiation or etoposide-induced DNA damage, results in the phosphorylation of the murine p53 protein at serine-389. Proc. Nat1. Acad. Sci. 95: 6399-6402.

$\mathrm{Lu}, \mathrm{X}$. and D.P. Lane. 1993. Differential induction of transcriptionally active p53 following UV or ionizing radiation: Defects in chromosome instability syndromes? Cell 75: 765778 .
Martinho, R.G., J.D. Lindsay, G. Flaggs, A.J. Demaggio, M.F Hoekstra, A.M. Carr, and N.J. Bentley. 1998. Analysis of Rad 3 and Chk1 protein kinases defines different checkpoint responses. EMBO I. 17: 7239-7249.

Matsuoka, S., M. Huang, and S.J. Elledge. 1998. Linkage of ATM to cell cycle regulation by the Chk 2 protein kinase. Science 282: $1893-1897$.

Mayo, L.D., J.J. Turchi, and S.J. Berberich. 1997. Mdm2 phosphorylation by DNA-dependent protein kinase prevents ineraction with p53. Cancer Res. 57: 5013-5016.

Mayr, G.A., M. Reed, P. Wang, Y. Wang, J.F. Schwedes, and P. Tegtmeyer. 1995. Serine phosphorylation in the $\mathrm{NH}_{2}$ terminus of p53 facilitates transactivation. Cancer Res. 55: 24102417.

Meek, D.W. 1998. Multisite phosphorylation and the integration of stress signals at p53. Cell Signal 10: 159-166.

Meek, D.W., S. Simon, U. Kikkawa, and W. Eckhart. 1990. The p53 tumour suppressor protein is phosphorylated at serine 389 by casein kinase II. EMBO J. 9: 3253-3260.

Midgeley, C.A. and D.P.Lane. 1999. P53 protein stability in tumor cells is not determined by mutation but is dependent on Mdm2 binding. Oncogene 15: 1179-1189.

Milne, D.M., R.H. Palmer, D.G. Campbell, and D.W. Meek. 1992. Phosphorylation of the p53 tumour-suppressor protein at three $\mathrm{N}$-terminal sites by a novel casein kinase I-like enzyme. Oncogene 7: 1361-1369.

Milne, D.M., D.G. Campbell, F.B. Caudwell, and D.W. Meek. 1994. Phosphorylation of the tumor suppressor protein p53 by mitogen-activated protein kinases. J. Biol. Chem. 269: 9253-9260.

Milne, D.M., L.E. Campbell, D.G. Campbell, and D.W. Meek 1995. p53 is phosphorylated in vivo and in vivo by an ultraviolet radiation-induced protein kinase characteristic of the c-Jun kinase, JNK1. J. Biol. Chem. 270: 5511-5518.

Momand, J., G.P. Zambetti, D.C. Olson, D. George, and A.J. Levine. 1992. The $m d m-2$ oncogene product forms a complex with the p53 protein and inhibits p53-mediated transactivation. Cell 69: 1237-1245.

Oliner, J.D., J.A. Pietenpol, S. Thiagalingam, J. Gyuris, K.W. Kinzler, and B. Vogelstein. 1993. Oncoprotein MDM2 conceals the activation domain of tumour suppressor p53. $\mathrm{Na}$ ture 362: 857-860.

Peng, C.-Y., P.R. Graves, R.S. Thoma, Z. Wu, A.S. Shaw, and H. Piwnica-Worms. 1997. Mitotic and G2 checkpoint control: Regulation of 14-3-3 protein binding by phosphorylation of cdc25C on serine-216. Science 277: 1501-1505.

Prives, C. 1998. Signaling to p53: Breaking the MDM2-p53 circuit. Cell 95: 5-8.

Sakaguchi, K., H. Sakamoto, M.S. Lewis, C.W. Anderson, J.W. Erickson, E. Appella, and D. Xie. 1997. Biochemistry 36: 10117-10124.

Sakaguchi, K., J.E. Herrera, S. Saito, T. Miki, M. Bustin, A. Vassilev, C.W. Anderson, and E. Appella 1998. DNA damage activates p53 through a phosphorylation-acetylation cascade. Genes \& Dev. 12: 2831-2841.

Sanchez, Y., C. Wong, S.R. Thoma, R. Richman, Z. Wu, H. Piwnica-Worms, and S.J. Elledge. 1997. Conservation of the Chk1 checkpoint pathway in mammals: Linkage of DNA damage to Cdk regulation through Cdc25. Science 277: $1497-1500$.

Sarkaria, J.N., R.S. Tibbetts, E.C. Busby, A.P. Kennedy, D.E. Hill, and R.T. Abraham. 1998. Inhibition of phosphoinositide 3-kinase related kinases by the radiosensitizing agent wortmannin. Cancer Res. 58: 4375-4382.

Schwartz, D. and V. Rotter. 1998. P53-dependent cell cycle control: Response to genotoxic stress. Sem. Cancer Biol. 8: 325- 
Shieh et al.

336.

Shaulian, E., A. Zauberman, J. Milner, E.A. Davies, and M. Oren. 1993. Tight DNA binding and oligomerization are dispensable for the ability of p53 to transactivate target genes and suppress transformation. EMBO I. 12: 2789-2797.

Shieh, S.-Y., M. Ideda, Y. Taya, and C. Prives. 1997. DNA damage-induced phosphorylatin of p53 alleviates inhibition by MDM2. Cell 91: 325-334.

Shieh, S.-Y., Y. Taya, and C. Prives. 1999. DNA damage-inducible phosphorylation of p53 at N-terminal sites including a novel site, Ser20, requires tetramerization. EMBO J. 18: $1815-1823$.

Siliciano, J.D., C.E. Canman, Y. Taya, K. Sakaguchi, E. Appella, and M.B. Kastan. 1997. DNA damage induces phosphorylaiton of the amino terminus of p53. Genes \& Dev. 11: 34713481 .

Smith, G.C., N. Divecha, N.D. Lakin, and S.P. Jackson. 1999. DNA-dependent protein kinase and related proteins. Biochem. Soc. Symp. 64: 91-104.

Tibbetts, R.S., K.M. Brunbaugh, J.M. Williams, J.N. Sarkaria, W.A. Cliby, S.-Y. Shieh, C. Prives, and R.T. Abraham. 1999. A role for ATR in the DNA damage-induced phosphorylation of p53. Genes \& Dev. 13: 152-157.

Unger, T., T. Juven-Gershon, E. Moallem, M. Berger, R.V. Sionov, G. Lozano, M. Oren, and Y. Haupt. 1999. Critical role for Ser20 of human p53 in the negative regulation of p53 by Mdm2. EMBO J. 18: 1805-1814.

Walworth, N.C. and R. Bernards. 1996. rad-dependent response of the chk1-encoded protein kinase at the DNA damage checkpoint. Science 271: 353-356.

Walworth, N., S. Davey, and D. Beach. 1993. Fission yeast chk1 protein kinase links the rad checkpoint pathway to $c d c 2$. Nature 363: 368-371.

Wang, Y. and C. Prives. 1995. Increased and altered DNA binding of Human p53 by S and G2/M but not G1 cyclin-dependent kinases. Nature 376: 88-91.

Weinert, T. 1998. DNA damage checkpoints update: Getting molecular. Curr. Opin. Genet. Dev. 8: 185-193.

Zeng, Y., K.C. Forbes, Z. Wu, S. Moreno, H. Piwnica-Worms, and T. Enoch. 1998. Replication checkpoint requires phosphoryltion of the phosphatase Cdc25 by Cds1 or Chk1. Nature 395: 507-510. 


\section{Erratum}

Genes \& Development 14: 289-300

The human homologs of checkpoint kinases Chk1 and Cds1 (Chk2) phosphorylate p53 at multiple DNA damage-inducible sites

Sheau-Yann Shieh, Jinwoo Ahn, Katsuyuki Tamai, Yoichi Taya, and Carol Prives

The authors' affiliations were inadvertently listed incorrectly. The correct affiliations are as follows:

\section{Shieau-Yann Shieh, ${ }^{1,2}$ Jinwoo Ahn, ${ }^{1}$ Katsuyuki Tamai, ${ }^{3}$ Yoichi Taya, ${ }^{4}$ and Carol Prives ${ }^{1,5}$ \\ ${ }^{1}$ Department of Biological Sciences, Columbia University, New York, New York 10027 USA; ${ }^{3}$ Cyclex Company Ltd., Nagano, 396-0002, Japan; ${ }^{4}$ National Cancer Research Institute, Tokyo 104, Japan}

\footnotetext{
${ }^{2}$ Present address: Institute of Biomedical Sciences, Academia Sinica, Nankang, Taipei 11529, Taiwan.
} 


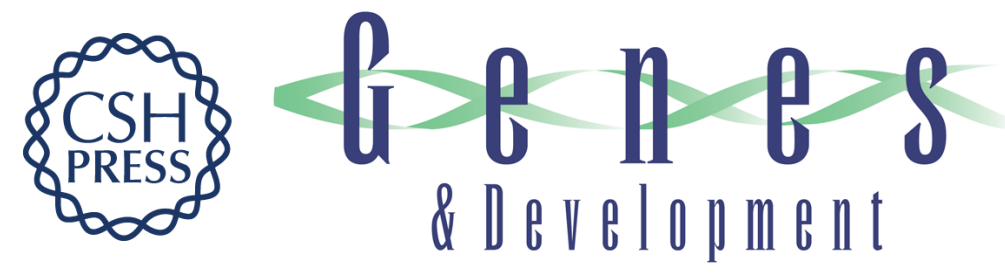

\section{The human homologs of checkpoint kinases Chk1 and Cds1 (Chk2) phosphorylate p53 at multiple DNA damage-inducible sites}

Sheau-Yann Shieh, Jinwoo Ahn, Katsuyuki Tamai, et al.

Genes Dev. 2000, 14:

Access the most recent version at doi:10.1101/gad.14.3.289

\section{Related Content Genes Dev. March, 2000 14: 750}

References This article cites 76 articles, 36 of which can be accessed free at: http://genesdev.cshlp.org/content/14/3/289.full.html\#ref-list-1

Articles cited in:

http://genesdev.cshlp.org/content/14/3/289.full.htmI\#related-urls

\section{License}

Email Alerting

Service

Receive free email alerts when new articles cite this article - sign up in the box at the top right corner of the article or click here.

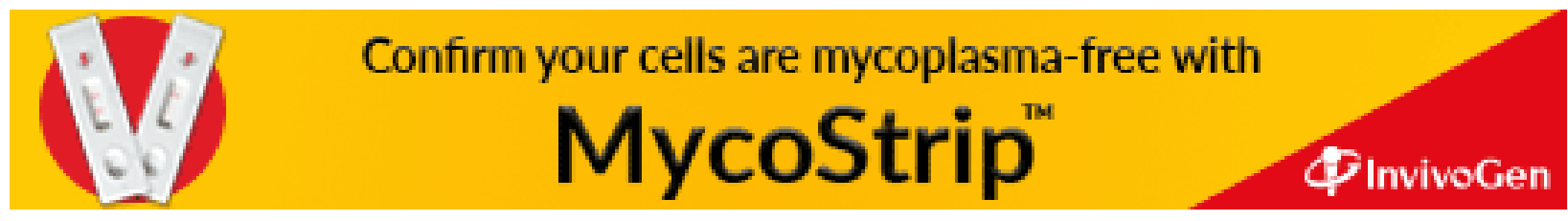

